TranscUlturAl, vol. 1, (4) 2011, 103-122.

http://ejournals.library.ualberta.ca/index.php/TC

\title{
The Other Side of the Coin of Lexical Borrowing From Arabic into English
}

Mohammad Ahmad Thawabteh

Al-Quds University

\section{Introduction}

Translation is recognised as a device for overcoming the various linguistic and cultural obstacles that emerge in any intercultural exchange between different languages and cultures and that, throughout history, have made such exchanges so complicated. Translating across languages and cultures enhances the interactive dimension and facilitates the search for and invention of new lexicons to develop the meaning of the receptor language in a new signifying context. Kelly as cited in Hermans (1999: 37) aptly remarks, "Western Europe owes its civilization to translators" (1). For instance, the flood of foreign borrowings into English has greatly influenced the language, to the point that approximately sixty percent of English lexicon is due to borrowing (Daher 2003).

Many cultures such as Arab, Spanish, and English (to mention only a few) have gained impetus through translation. Qasim writes: "Translation represented a milestone in Islamic and Arab culture and enabled the Muslims and Arabs to become well-versed in other cultures" (Qasim 23). It is certain that, in the words of Mouakket, "the Arabs owed the Greeks the initiative and the starting point towards reasoning. But no sooner had they taken the first step, than their vigorous and earnest desire for knowledge surpassed that of Greeks in many fields" (25). Arabic was then a lingua franca of Europe. Salloum and Peters argue that:

"Arabic was the intellectual and scientific language of the entire scholastic world. The men of letters and science had to know Arabic if they wanted to produce works of arts and science [...]. Arab Andalusia by itself produced more works in Arabic than were produced in all the languages of Europe.” (23)

For Salloum and Peters, Spanish absorbed and then kept over 8000 words from Arabic, of which 2300 are place names (23; see also Thawabteh, 6). In the same vein, Versteegh states 
TranscUlturAl, vol. 1, (4) 2011, 103-122.

http://ejournals.library.ualberta.ca/index.php/TC

that, "From Spain, a large amount (sic) of Arabic words were transmitted to other countries in Western Europe” (228), a point with which Salloum and Peters agree:

"There are over 6.500 English basic words of Arabic origin or transmitted through Arabic.

These words are from different subjects: like architecture, agriculture, art, astronomy, commerce, geography, industry, literature, mathematics, mechanics, medicine, music and physics which Arab has great contributions in these subjects." (23)

It is probably fair to state that translation contributes to the enrichment of cultures and "reflect[s] to some degree the paths of cultural influence" (Abdel Rahman 33). It is also possible to add that Arabic was one of few languages that had cultural impact globally. Sapir explains: "There are just five languages that have had an overwhelming significance as carriers of culture. They are classical Chinese, Sanskrit, Arabic, Greek and Latin” (194). Such a claim, however, can probably be amorphous as applied to English, being today's lingua franca, or to other languages like French.

\section{Borrowing}

Borrowing is not a new phenomenon in the history of language contact. It is considered, in the words of Armstrong, to be "one of the ways in which a language renews its lexicon" (143), and it has been one of the translation strategies employed in interlingual communication. This strategy is based on the transference of an item from a SL into a TL at different levels, with varying degrees, e.g., 'phonological', 'orthographic', 'morphological', 'semantic', 'lexical' and 'phraseological (Humbley and Mene as cited in Capuz-Gómez 84). Haugen speaks of three different methods for translating foreign signifiers crosslinguistically: "On the morphemic level this means a division into loanwords (no substitution), loanblends (some substitution) and loanshifts (complete substitution). Loanblends are usually called hybrid loans. Loanshifts include semantic loans and loan translation (calque)" (59-60; emphasis in original). Borrowing then takes three forms, an idea that can likely be generalized to most languages as no language seems to be protected from foreign borrowings. For instance, a seamless influx of English borrowings into Arabic has been obvious for many years and affects a multitude of fields. It also paves the way for crosscultural innovation such as the introduction of new technology. Arabic had to incorporate new cultural words and idioms. By the same token, borrowings from Arabic into English have undergone shifts that would conform to English culture behaviour or expectations. 
TranscUlturAl, vol. 1, (4) 2011, 103-122.

http://ejournals.library.ualberta.ca/index.php/TC

As far as the present study is concerned, two types of translation are taken into consideration, namely translation by loanword and translation by calque, the latter being comprised of three methods of translation: calque with extension, calque with reduction and calque with expansion and substitution (Al-Najjar 81-83).

\subsection{Loanword}

It is true that Arabic and English are linguistically remote languages; while the former belongs to a Semitic language family, the latter is an Indo-European language. This means that each language has its own subtle nuances in terms of phonology, syntax, semantics, pragmatics, stylistics, and culture. By definition, loanword refers to the phonemic structure of Arabic when transferred into English. For example, the Arabic 'q' in qanāh (lit. 'canal'), ' $\mathrm{x}$ ' in maxąan (lit. 'storehouse') and 't' țūb (lit. 'adobe') are diffused into English with some alterations at the phonological level to mesh with English phonological system.

\subsection{Calque or Loan Translation}

Al-Najjar defines calque as "a phrase or compound word which translates a foreign expression part by part" (86; see also Haugen 1956). Following on from Al-Najjar, who speaks of six patterns of borrowings from English into Arabic, we could find three patterns in transference in the other direction, from Arabic into English.

\subsubsection{Calque with Extension}

The Arabic signifier xarūb is rendered into 'carob' and the constituent 'powder' is added to the English translation. Probably such extension can be justified in terms domesticating the Arabic signifier in the English context (see Example 12 below for a further discussion on 'carob').

\subsubsection{Calque with Reduction}

One or more constituents of the Arabic signifier are scaled down as shown in Example 1 below in which the masculinity of xalifa (lit. 'caliph') is not respected- thus the feasibility of a caliph to be a woman or child.

\subsubsection{Calque with Expansion and Substitution}

More constituents of Arabic signifiers are replaced with English signifiers. For example, the word maxzan (lit. 'storehouse') puts forward another interpretation in English: a 'publication with a paper cover issued regularly' (Collins Cobuild English Dictionary (CC) 2002). 
TranscUlturAl, vol. 1, (4) 2011, 103-122.

http://ejournals.library.ualberta.ca/index.php/TC

\section{Connotation and Denotation}

Translating languages with little cultural affinity (e.g., English and Arabic) is fraught with several difficulties as Sofer explains:

"The conscientious Arabic translator is aware of the generic difficulties in working with two languages as different from each other as English and Arabic. [...], there are vast cultural differences between a Western language such as English and a Semitic language like Arabic. One cannot translate these languages without paying attention to these cultural differences." (65-6)

In translation, "whenever a new signifier is transferred from a source culture into a receptor culture, the linguistic system of the receptor culture is called upon to coin a signifier for that borrowed signifier" (Al-Najjar 77). The corollary of a signified is a signifier in the receptor culture. While "the signifier and signified work together to give rise to a sign which has denotative meaning, the resulting sign [...] requires an additional meaning, [and] becomes a new signifier in search of connotative meaning" (Hatim and Mason 112). For communication to take place, argues Fisk,

"I have to create message out of things. This stimulates you to create a meaning for yourself that relates in some way to the meaning I generated in my message in the first place. The more we share the same codes, the more we use the same sign system, the closer our two meanings of the message will approximate to each other." (39)

Related to this discussion are the notions of 'connotation' and 'denotation.' Shunnaq argues that denotation involves "the relationship between lexical items and non-linguistic entities to which they refer, thus [...] equivalent to referential, conceptual, propositional, or dictionary meaning" (36-37). Connotation, however, refers to our strong, weak, affirmative, negative, or emotional reaction to words (Nida and Taber 92). In addition to the denotative meanings of the SL signifier, the new transformed signifier in the receptor culture is expected to reflect as many connotative meanings of the SL signifier as possible. It should be noted that connotation is related to communication context and pragmatics. A SL signifier may be used in the SL in a different way from the connotative meanings accrued in the receptor culture. In Example 2, for instance, the pragmatic use of Arabic 'sheikh' is worth noting. The item has drifted away from its semantic load; the Arabic vocative ya plus sheikh, e.g., rub ya sheikh (lit. 'go away O sheikh') is formulaic, commonly used to tell someone to go away, with intonation taken into full consideration. With rising intonation, it may be used as a 
TranscUlturAl, vol. 1, (4) 2011, 103-122.

http://ejournals.library.ualberta.ca/index.php/TC

euphemistic item to mean more or less 'eff-off. With falling intonation, however, it is a dysphemistic item meaning 'fuck off'.

\section{Translation Strategies}

Krings defines translation strategy as a "translator's potentially conscious plans for solving concrete translation problems in the framework of a concrete translation task" (18). Borrowing is one of the several translation strategies that can be employed in the course of translation and mainly consists of two types: (1) adopting and retaining the form used in the donor language, bearing in mind the receptor's own phonological and morphological systems; and (2) calque, in which a foreign word or phrase is translated and incorporated into another language, for example 'Arabicization' to use Farghal and Shunnaq's word (23; see also Nida and Taber 1969; Molina and Hurtado Albir 2002; Daher 2003).

Arguably, the translator can be viewed in terms of the 'plenipotentiary powers's/he would exercise on behalf of the TL audience, removing the SL linguistic and cultural nuances from fully coming into the translated text. Similarly, but more precisely, Venuti (The Translator 20) speaks of two translation strategies, namely 'domestication' and 'foreignization,' which shall be used for our purpose in the discussion of Arabic borrowings into English. These two strategies are valid at text level, and generally at word level. The domesticating method involves "an ethnocentric reduction of the foreign text to targetlanguage cultural values, bringing the author back home" (Venuti, The Translator 20). It "masks both the translator's work and the asymmetrical relations -cultural, economic, political- between English-language nations and their others worldwide" (Venuti, The Translator 38). Venuti suggests that "insofar as foreignizing translation seeks to restrain the ethnocentric violence of translation, it is highly desirable today, a strategic cultural intervention in the current state of world affairs, pitched against the hegemonic Englishlanguage nations and the unequal cultural exchanges in which they engage their global others" (The Translator 20). Schleiermacher considers two methods for bringing the author and the reader together: "Either the translator leaves the author in peace as much as possible and moves the reader toward him; or he leaves the reader in peace as much as possible and moves the writer toward him" (49). The foreignizing method, however, involves "an ethnodeviant pressure on those values to register the linguistic and cultural differences of the foreign text [sending the reader abroad]" (Venuti, The Translator 81). 
TranscUlturAl, vol. 1, (4) 2011, 103-122.

http://ejournals.library.ualberta.ca/index.php/TC

We should note, however, that much criticism has been levelled at Venuti's concepts due to potential oscillation between 'domestication' and 'foreignization' in the course of translation (e.g., Hermans 1999; Pym 1996 and Baker 2007). Baker in particular criticises Venuti's 'sweeping dichotomies' of foreignizing and domesticating strategies:

"Apart from reducing the rich variety of positions that translators adopt in relation to their texts, authors and societies, these dichotomies also obscure the shifting positions of translators within the same text they reduce the intricate means by which a translator negotiates his or her way around various aspects of a text into a more-or-less straightforward choice of foreignizing versus domesticating strategy." (Baker Reframing 152)

With this in mind, we argue that such shifts between the two poles occur even at word level. For instance, both models are employed concomitantly as to 'carob,' a loanword whose phonetic representations reflect phonemic infiltrations of Arabic xarüb (lit. 'carob'), i.e., the Arabic sound still surface in the English 'carob,' hence foreignization is observed. The same word bears witness to domestication (see Example 12). It is also possible to recognise the degree of foreignness in, to mention only a few, siesta from Spanish, fin de siècle from French, and kibbutz from Hebrew, let alone the many connotations these words in origin still hold. In terms of foreignization, the Arabic voiceless velar fricative ' $\mathrm{X}$ ' is changed into voiceless velar stop ' $\mathrm{K}$ ' in accordance with the English sound system. Similarly, the Spanish siesta and Hebrew kibbutz, are modified to fit the English phonological system. However, the French sound in fin de siècle is more or less kept in English, although it is domesticated to a certain degree. While it is used in French to mean the end of a century, it is used in English "to describe something that is thought to be typical of the end of the nineteenth century, especially when it is considered stylish or exaggerated" (CC).

Likewise, Toury admits that any translation occupies a position on a continuum between two poles, namely 'adequacy' defined as "adherence to source text norms" (56-9), and 'acceptability' defined as "subscription to norms originating in the target culture" (56-9). In other words, when the SL norms prevail, the TL will be adequate; however, when the norms of the TL prevail, the TL will be acceptable. Toury claims that no translation is ever said to be completely adequate or acceptable (56-9). 
TranscUlturAl, vol. 1, (4) 2011, 103-122.

http://ejournals.library.ualberta.ca/index.php/TC

\section{Methodology}

This paper examines 15 borrowings from Arabic into English following Venuti's notions of 'domestication' and 'foreignization.' The borrowings are first identified to have undergone semantic shifts from their original meanings, with varying degrees, and then have accrued additional meanings in the receptor culture. We examine these borrowings based on the Arabic dictionary Lisän al 'Arab (2010) (henceforth LA) and the new meanings in the receptor language building on English Collins Cobuild (2002) (henceforth CC) and the Concise Oxford English Dictionary (2004) (henceforth COED). The borrowings are occasionally analyzed in accordance with modern use of Arabic. To make this paper easy to read, the selected words are discussed under four different types, namely religion, architecture, agriculture, and animals.

\section{Analysis and Discussion}

The theoretical framework established thus far requires that we examine some examples in order to make our argument solid. A classification of borrowings is made for the purposes of the paper. It should be noted that in almost all of the examples discussed below, loanword strategy along with calque or loan translation strategies are employed.

\subsection{Religion}

That religion constitutes a fertile soil for ideological leanings is taken for granted. Islam is a case in point. Due to the fact that items relating to religion are hard to translate, opting for borrowing turns out to be a solution. The first study lexical item in Example 1 below shows how the item 'caliph' has undergone drastic semantic shifts from its original meanings.

Example 1: (caliph)

LA Religious male successors of Prophet Muhammad.

CC Was a Muslim ruler.

COE The chief Muslim civil and religious ruler, regarded as the $D \quad$ successor of Muhammad.

With very limited connotative meanings probably obtained through domestication, $C C$ highlights time difference - Caliph was a title used by Muslim rulers in the past. In contrast, time difference is not made by COED. What is interesting about the CC and COED definitions is the semantic expansion which brings about an ideologically loaded item that fully contradicts Muslims' credo and ethos, namely the possibility of a caliph being a woman 
TranscUlturAl, vol. 1, (4) 2011, 103-122.

http://ejournals.library.ualberta.ca/index.php/TC

or child. This 'semantic expansion' explicitly appears in $C C$, according to which, "The ruler of a country is the person who rules the country," and the person can be a man, woman, or child. The domestication process pervades the definition given in CC. However, $L A$ stresses that xalifa (lit. 'caliph') is a title used in the past by Muslims to describe the political and religious successors of Prophet Muhammad. These should have such authority and religious power needed to manage Muslims' public affairs in accordance with Islamic jurisdiction, with gender distinction taken into full consideration (i.e., xalifa can only be masculine). Further connotations are shown in recent uses of 'caliph', the most important of which is an obligation put to Muslims to pursue a caliph with great diligence in order to manage their worldly affairs. It is plausible to argue that the domestication strategy is crystal-clear in the definitions in question. The receptor culture leanings are observable and the asymmetrical political relation between English and Arabic is masked. While in the former, a ruler is part of political and social structures, in the latter, the caliph is under the sway of Allah or Islamic doctrine that is divinely ordained. Caliphate is a ruling system that considers the Muslim caliph as the divine shadow on earth. To further elaborate this issue, take 'sheikh' in Example 2 below.

\section{Example 2: (sheikh)}

$L A \quad$ 1. Someone who is white-haired.

2. The period of years especially after fifty towards the end of your life.

CC A male Arab chief or ruler.

COE 1. An Arab leader, especially the chief or head of a tribe, $D \quad$ family, or village.

2. A leader in a Muslim community or organization.

Unlike the definition of 'caliph' suggested by $C C$, the one here highlights gender distinction. Extra definitions are offered by $C O E D$, i.e., calque with expansion and substitution, but the denotative meanings are still far beyond the intended meanings of the SL. Similarly, in recent socio-cultural practices, 'sheikh' is used in Arab culture as a title to address people of high standing in some Arabian Gulf states like UAE and Qatar, and also to address a professor (Hatim and Mason 66), a point with which Sharyan (2009, ) agrees: 'sheikh' is a "form of address that has no parallel in English. It may be used to address someone who memorised the Koran ${ }^{1}$ or the clergy man in Islam. It is also a form of deference for someone who is old and religious."

$1 \quad$ Alternative spelling to Qur'an. 
TranscUlturAl, vol. 1, (4) 2011, 103-122.

http://ejournals.library.ualberta.ca/index.php/TC

The definitions offered by $C C$ and COED are divergent from those given by LA. Such narrow definitions, presumably due to the domestication offered by CC or COED, are likely to pose numerous problems in the translation from Arabic into English. It is possible that censorship is observed, a translation strategy which, according to Scandura, would be opted for to protect the TT audience from any utterances that are undesirable, i.e., that would be culturally or religiously considered as dreadful expressions (125). In this vein, Baker argues that "In some translation contexts, being polite can be far more important than being accurate. A translator may decide to omit or replace whole stretches of text which violate the reader's expectations" (In Other Words 234). The opposite should also hold true. Afflicted by censorship, the target audience is deprived of the SL layers of meaning (i.e., connotative meaning) captured through experience and use and only the modern connotative meanings of the lexical item in question are accessible to the audience. This is arguably true in the context of Western hegemony in which translation is viewed as a means to express the attitudinal meanings of the colonizer and to promote its ideological positions (see also Venuti The Translator 1995). In this regard, Alvarez and Vidal point out that

\footnotetext{
"Translators are constrained in many ways: by their own ideology; by their feelings of superiority or inferiority towards the language in which they are writing the text being translated; by the prevailing poetical rules at that time; by the very language in which the texts they are translating is written; by what the dominant institutions and ideology expect of them; by the public for whom the translation is intended." (6)
}

For more religion-related borrowings, consider Example 3 below where domestication has masked 'jihad,' giving rise to one of the most deep-seated problems between the West and Islam.

Example 3: (jihad)

LA A war or struggle against enemies and unbelievers.

CC A holy war which Islam allows Muslims to fight against those who reject its teachings.

COE 1. A war or struggle against unbelievers.

D 2. (Greater jihad) the inner spiritual struggle against sin.

In example 3, calque with reduction strategy is observed. One of the problems shown in CC's definition of 'jihad' is the fact that it highlights perhaps only one fourth of its shades of meanings by means of domesticating method, namely waging 'a holy obligatory war against unbelievers.' 'Ethnocentric reduction' in which other meanings, such as 'jihad by/of the 
TranscUlturAl, vol. 1, (4) 2011, 103-122.

http://ejournals.library.ualberta.ca/index.php/TC

tongue,' 'jihad by/of the hand,' and 'jihad against one's self is exercised, only the last of which is offered by COED. As for 'jihad by the tongue,' it is a kind of jihad whereby a person should be able to state the truth forcibly. On the other hand, 'jihad of the tongue' is restraining from backbiting, using bad language, and so forth. 'Jihad by the hand,'refers more or less to a holy war fought against those who reject the teachings of Islam. Nevertheless, 'jihad of the hand' aims at refraining from doing bad things, such as murdering someone. As can be noted from the political upheavals in Iraq, Palestine, Afghanistan, etc. 'jihad' has always been linked with terrorism, as Rieschild argues, and that its English sense has developed negative connotations more equivalent to "Un-holy war" (see also Baker Translation and Conflict 70). These negative connotations hinge on the notion of domestication. In a sense, the fact that $C C$ and COED take a limited view of 'jihad' seems to be ideologically motivated. The foreign text is imprinted with values specific to the target culture.

Likewise, in Example 4, the signifieds designated to 'imam' lack several connotations that already exist in the SL, namely a sense of deference, a prophet, an authoritative person who would answer an Islamic question, and many others.

Example 4: (imam)

LA Anyone leading people righteously

CC A religious leader, especially the leader of a Muslim community or the person who leads the prayers in a mosque.

COE 1 The person who leads prayers in a mosque.

D $\quad 2$ (Imam) a title of various Muslim leaders, especially of one succeeding Muhammad as leader of Shiite Islam.

Foreignization is present in almost all of the definitions given in Example 4. In CC and $C O E D$ definitions, calque with reduction strategy is employed whereby only one shade of meaning for 'imam' is mentioned, thus domestication is also possible.

Due to the importance of women in Arab culture, nomenclature of women's attributes is done meticulously in socio-cultural practices, e.g., 'harem' (see Example 5 ). It highlights 'ir $\underline{d}$ (roughly honour), very much "relevant to some patriarchal societies such as Arab and Islamic societies, among others [...] 'ir $\underline{d}$ is the bread-and-butter matter to almost all Arab and Islamic societies indeed" (Thawabteh 30; emphasis in original). Traditionally, "ir $\underline{d}$ in Arabic is "often associated with the family's honour. Men are morally and socially responsible for the acts of their female relatives. A sexual offence on a woman causes her 
TranscUlturAl, vol. 1, (4) 2011, 103-122.

http://ejournals.library.ualberta.ca/index.php/TC

"ird to be lost and cannot be regained" (Shunnaq 56). To illustrate this point, consider Example 5 below.

Example 5: (harem)

$L A$ 1. A man's harem is for whom he fight.

2. Lust of animals that have cloven hooves, e.g., cows, sheep, goats, etc. for male partners.

CC If a man, especially a Muslim, has several wives or sexual partners living in his house, they can be referred to as his harem.

COE 1 The separate part of a Muslim household reserved for D wives, concubines, and female servants.

2 The wives (or concubines) of a polygamous man.

3 A group of female animals sharing a single mate.

The definitions given by $C C$ and COED seem to be far beyond the scope of those displayed in $L A$, namely, equal dignity and honour of male and female. According to the first definition offered by LA, the primary duty of men is to provide protection for women. Even today, Arab men stake out women protection practice. It is true that Arab societies are patriarchal ones where men are seen as strong and women weak, men as rational and women irrational, and men as leaders and women followers.

There are many problems associated with the animal-related definitions of the COED, particularly a large semantic shift from those suggested by LA. For further illustration of religion-loaded borrowings, take Example 6 in which a drift in the semantic traits is obvious.

Example 6: (halal)

$L A \quad$ What is allowable in Islam.

CC Halal meat is meat from animals that have been killed according to Muslim law.

COE 1. Denoting or relating to meat prepared as prescribed by

D Muslim law.

2. Halal meat.

It is clear that domestication masks the foreignness of the item 'halal' and falsely creates a homogeneous target language, only highlighting meat as equivalent to 'halal' as $C C$ and COED suggest. This item is generic in Arab-Islamic context and is considered the crucial part of Islamic credo. It comprises not only the meat, but it also includes all walks of life. For example, marriage is 'halal', i.e., commendable in Islam whereas adultery is 'haram' 
TranscUlturAl, vol. 1, (4) 2011, 103-122.

http://ejournals.library.ualberta.ca/index.php/TC

(not 'halal'), i.e., abominable. Abiding by Islamic jurisdiction is 'halal' whereas the opposite is 'haram'.

Foreignization is also noticeable in Example 7. Most of SL constituents are retained as $C C$ and $C O E D$ suggest fasting from sunrise to sunset. However, it is also noticeable that domestication is an ideological process.

Example 7: (Ramadan)

LA The name of a lunar month when Muslim fast from dawn to sunset.

CC The ninth month of the Muslim year, when Muslims do not eat between the rising and setting of the sun. During Ramadan, Muslims celebrate the fact that it was in this month that God first revealed the words of the Quran ${ }^{2}$ to Mohammed $^{3}$.

COE The ninth month of the Muslim year, during which strict $D \quad$ fasting is observed from dawn to sunset.

Ramadan is a sacred month in Islam and has a wide variety of connotative meanings, other than the shallow definitions offered by $C C$ and $C O E D$. Domesticating process provides the backdrop against which different burgeoning and elastic interpretations could be made. For example, the use of 'strict' by COED relegates fasting to the bottom of socio-religious practices. COED tries to include a feeling that fasting is severe and must always be completely obeyed. It should be noted, however, that Ramadan observers not only have to refrain from eating foods, smoking cigarettes, and having sexual intercourse, but they have also to cease arguing, speaking unkindly, etc. They have to do only good deeds.

\subsection{Architecture}

There is much potential for borrowings from a developed culture into a less developed one. The development of Arab architecture, particularly in Granada, Seville, and Cordova was a catalyst for numerous borrowings.

Example 8: (canal)

$L A \quad$ Spear, well and people who have a solid stature and thin waist

CC 1A long, narrow stretch of water that has been made for boats to travel along or to bring water to a particular area.

2 A narrow tube inside your body for carrying food, air, or other substances.

COE 1An artificial waterway allowing the passage of boats inland or

$2 \quad$ Alternative spelling to Qur'an.

3 Alternative spelling to Muhammad. 
TranscUlturAl, vol. 1, (4) 2011, 103-122.

http://ejournals.library.ualberta.ca/index.php/TC

D conveying water for irrigation.

2 A tubular duct in a plant or animal conveying food, liquid, or air.

Arabic qanăh ('canal') indicates three different meanings as cited in $L A$, only one of which survives in English according to $C C$ and $C O E D$ as shown in Example 8. The strategy opted for is calque with expansion and substitution. For the sake of illustration, consider Example 9 .

Example 9: (alcove)

LA Vault

CC A small area of a room which is formed by one part of a wall being built further back than the rest of the wall.

COE A recess, typically in the wall of a room.

$D$

The item 'alcove' acquires more meanings as CC and COED show. In Arabic, 'vault' is an arched roof or ceiling, usually screened off by pillars, a balustrade, or drapery; also, it includes a secure room where money and other valuable things can be kept safely.

In Example 10, the Arabic maxzan only denotes a storehouse whereas in English it acquires extra meanings more bound to English culture, e.g., 'publication.' Interestingly, Arabic uses another loan-lexicon from English to designate 'magazine,' namely majalah. As can be observed, calque with expansion and substitution is employed. It ensues, therefore, that a domesticating method is adopted.

Example 10: (magazine)

LA Storehouse for grain, arms, ammunition, explosives etc.

CC 1 Publication with a paper cover which is issued regularly, usually every week or every month, and which contains articles, stories, photographs, and advertisements.

2 In an automatic gun, the magazine is the part that contains the bullets.

COE 1 A periodical publication containing articles and

D illustrations. A regular television or radio programme comprising a variety of items.

2 A chamber for holding a supply of cartridges to be fed automatically to the breech of a gun.

3 A store for arms, ammunition, and explosives.

It seems plausible to say that foreignness is retained in English as can be shown in Example 11. The Spanish adobar is currently used in some Arab countries, such as Jordan and Palestine, to mean starting building works.

Example 11: (Adobe) 
TranscUlturAl, vol. 1, (4) 2011, 103-122.

http://ejournals.library.ualberta.ca/index.php/TC

LA Clay and mud bricks

CC A mixture of mud and straw that is dried into bricks in the sun and used for building, especially in hot countries.

COE A kind of clay used to make sun-dried bricks.

D

\subsection{Agriculture}

Botanical and horticultural Arabic-origin terms in English are numerous. In view of the agricultural development by Arabs in Andalusia, agriculture-related borrowings diffused across Europe.

Example 12: (carob)

LA 1. Cucumber-sized sweet edible pod used to make jam.

2. Prophet Mohammed said, "In everyday a plant grew in Temple of Prophet Solomon. The prophet used to ask the plant what its name was, then it answered 'I am such and such a plant; I grew in such and such a place; and I am a medicine for such and such an illness". Prophet Solomon then ordained that the plant be cut down, dried, put into a small package and had its name written on it and what it was used for. When the last plant grew, Prophet Solomon asked what its name was, then it answered 'I am the carob', without uttering more words. It was then that the prophet realised that the Temple was going to be devastated. It was actually the end of Solomon kingdom, and no sooner had he known the name of the plant that he died [researcher's translation].

CC 1 a Mediterranean tree that stays green all year round. It has dark brown fruit that tastes similar to chocolate.

2 The dark brown fruit of the carob tree can be referred to as carob. It is often made into powder and used instead of chocolate.

COE 1The edible brownish-purple pod of an Arabian tree, from

D which a powder is extracted for use as a substitute for chocolate.

2 The tree which yields carob pods.

The loanword in Example 12 tends to be culture-specific. First, 'carob,' a Mediterranean tree, is a portion of the social reality in Arab culture (eg. In Syria, Lebanon, Palestine etc.). In traditional Palestinian cuisine, jam is made from 'carob,' which has been finely ground and dried in the sun, and it is believed to be refreshing when someone is thirsty during daylight. It is also used for making juice. Secondly, 'carob' has religious connotations, which have remained in the collective imagination of the Muslims as well as in their collective Islamic 
TranscUlturAl, vol. 1, (4) 2011, 103-122.

http://ejournals.library.ualberta.ca/index.php/TC

and social practices for decades. On the other hand, English speakers use it as a kind of chocolate as both $C C$ and $C O E D$ suggest.

Another item, as shown in Example 13, is worth mentioning. According to $L A$, the Arabic culinary term lüf is a herb for medication and, in modern times, a type of plant used in some Arab dishes, particularly by some Palestinians. According to $C C$, it indicates a kind of body sponge used for washing oneself. It is possible that English mixes up lifa (body sponge) with lüf (dish). Calque with expansion and substitution is employed, and a domesticating method is observed.

Example 13: (loofah)

$L A \quad$ Herb for medication

CC A long rough sponge-like piece of plant fibre which you use to scrub your body.

COE 1 The fibrous matter of the fluid-transport system of a

$D \quad$ marrow-like fruit, which is used dried as a bath sponge.

2 The tropical climbing plant of the gourd family which produces loofahs.

One of the most popular borrowings in English may be 'coffee,' a beverage in the Arab world. Originally, its name is linked to wine due to the strong effect it has on the brain.

Since wine is forbidden in Islam, drinking 'coffee' has become one of the social practices in Muslim and Arab countries. Coffee may be presented in a variety of ways all over the world.

Example 14: (coffee)

LA appetite suppressant, hence called wine

CC 1 Coffee is a hot drink made with water and ground or powdered coffee beans.

2Coffee is the roasted beans or powder from which the drink is made.

COE 1 A hot drink made from the roasted and ground

$D \quad$ bean-like seeds of a tropical shrub. Coffee seeds roasted and ground, or a powder made from them.

2 The shrub which yields coffee seeds.

CEOD states that 'coffee' goes back to $16^{\text {th }}$ century, coming from Arabic into English via Turkish. Salloum and Peters further point out that "Coffee was once so popular in Turkey that if a husband failed to keep his wife supplied with the brew, she had grounds for divorce" (34).

Applying the world view dogmatically to all social phenomena is no longer valid. Technology has proven that wine made from grapes and other fruits or vegetables differs 
TranscUlturAl, vol. 1, (4) 2011, 103-122.

http://ejournals.library.ualberta.ca/index.php/TC

from coffee made with water and ground or powdered coffee beans. It is no longer seen as a forbidden beverage.

\subsection{Animals}

The last study item is 'gazelle'. As can be noted, different signifieds as shown by CC and $C O E D$ are designated to it.

Example 15: (gazelle)
LA Deer
CC A type of small African or Asian deer. Gazelles move very quickly and gracefully.
COE 3 A small, slender African or Asian antelope,
$D \quad$ typically having curved horns and fawn-coloured with white underparts.

The Arabic 'gazelle,' dating back to the $17^{\text {th }}$ century, comes from French, probably via Spanish from Arabic (see COED; Salloum and Peters 49). It is clear that more semantic components are added to the Arabic signifier as CC and COED show; domesticating process comes to the fore.

\section{Conclusion}

This paper analyzes Arabic borrowings existing in English with a view to examining Venuti's 'foreignization' and 'domestication.' To better understand translation, and following Venuti (1995), the following points are made. First, translation is looked at as an ideologically-motivated task whereby connotations implied in the SL become 'leftover' in the TL. That is to say, the original shades of meanings have been sacrificed to the receptor culture. The borrowed words are imprinted with values very much specific to the target culture. For example, the Arabic 'jihad' viewed by TL audience as a synonym of terrorism is a case in point. Secondly, translation is viewed as an object that helps the target culture progress a step further. Venuti's ideas seem to be valid as English culture borrowed some of these terms when its language was not dominant. The simplest method of borrowing is by loanword in which foreignness at sound level, for example, is more or less retained, e.g., attuib (lit. 'the adobe'). 'Ethnocentric reduction' of the foreign lexical item to the target culture values is exercised by the receptor language (English), particularly when it comes to a more sophisticated process of borrowing, i.e., calque or loan translation. In this regard, $\mathrm{Al}-$ Najjar says: 
TranscUlturAl, vol. 1, (4) 2011, 103-122.

http://ejournals.library.ualberta.ca/index.php/TC

"Foreign signifiers transferred into Arabic as loanwords or loanblends [...] will either testify to how much the receptor language is culturally indebted to the source language from which those loans have been borrowed or to how much the receptor culture has progressed to catch up with world scientific and cultural progress.” (90)

The opposite is true with regards to Arabic-to-English translation. For example, the SL signifieds assigned to 'carob' and 'loofa' are extended, accruing extra signifieds related to the industrial development of the TL culture. Thirdly, an attempt to reproduce in TL all the SL linguistic and the cultural features, as faithfully as possible, seems to be questionable. Fourthly, the strategies employed in the dictionaries in question range from loanword strategy whereby some alterations at the phonological level of the Arabic item is done following English phonological system, to calque or loan translation strategy which in turn includes strategies of calque with extension, expansion, and substitution, and reduction, the last of which seems to be recurrent. Finally, the paper shows that in their attempts to produce domesticated/foreignized representations of the other language and culture, dictionaries did not seem to succeed, let alone the fact that Arabic and English belong to different language families. It is true that "to study ideology is to study the ways in which meaning serves to establish and sustain relations of domination" (Thompson 56). 
TranscUlturAl, vol. 1, (4) 2011, 103-122.

http://ejournals.library.ualberta.ca/index.php/TC

\section{REFERENCES}

Abdel Rahman, Wajih. "A Critical Linguistic Study of Lexical Borrowing in Arabic and English.” Journal of King Saud University 3.2 (1991): 33-66.

Al-Najjar, Majed. "Linguistic Methods for Translating Non-Arabic Signifiers into Arabic." Issues in Translation. Eds. Abdullah Shunnaq, Cay Dollarup \& Mohammed Saraireh. Amman: Irbid National University and Jordanian Translators' Association, 1989 77-94.

Alvarez, Román. \& Vidal, M. Carmen África. Eds. Translation, Power Subversion. Clevedon: Multilingual Matters, 1996.

Armstrong, Nigel. Translation, Linguistics, Culture: A French-English Handbook. Clevedon, Buffalo and Toronto: Multilingual Matters Ltd., 2005.

Baker, Mona. In Other Words: A Course Book on Translation. London: Routledge, 1992.

Baker, Mona. Translation and Conflict: A Narrative Account. London \& New York: Routledge, 2006.

Baker, Mona. "Reframing Conflict in Translation.” Social Semiotics 17.2 (2007): 151-169.

Capuz-Gómez, Juan. "Towards a Typological Classification of Linguistic Borrowing (Illustrated with Anglicisms in Romance Languages)." Revista Alicantina de Estudios Ingleses 10 (1997): 81-94.

Collins Cobuild English Dictionary. Version 4.11. Birmingham: HarperCollins Publishers, 2002. Concise Oxford English Dictionary. 11 $1^{\text {th }}$ ed. Oxford: Oxford University Press, 2004.

Daher, Jamil. "Lexical Borrowing in Arabic and English.” The Vocabula Review 5.5 (2003). Web 7 Jan. 2011, <http://www.vocabula.com/VRMAY03SS.asp>

Farghal, Mohammad \& Shunnaq, Abdullah. Translation with Reference to English and Arabic: A Practical Guide. Irbid: Dar Al-Hilal for Translation, 1999.

Fisk, John. Introduction to Communication Studies. Routledge: London \& New York, 1990. Hatim, Basil \& Mason, Ian. Discourse and the Translator. Londo New York: Longman, 1990. Haugen, Einar. Bilingualism in the Americans: A Bibliography and Research Guides. Ala: University Alabama Press, 1956.

Hermans, Theo. Translation in Systems. Manchester: St. Jerome, 1999.

Kelly, Louis. The True Interpreter. Theory and Practice of Translation in the West. Oxford: Blackwell, 1979. 
TranscUlturAl, vol. 1, (4) 2011, 103-122.

http://ejournals.library.ualberta.ca/index.php/TC

Krings, Hans. "Translation Problems and Translation Strategies of Advanced German Learners of French." Interlingual and Intercultural Communication. Eds. Juliana House \& Shoshana Blum-Kulka. Tubingen: Gunter Narr, 1986. 263-75.

Lisan al Arab. 25 Feb. $2010<$ http://www.ghazali.org/arabic/lisanal-arab.zip>.

Molina, Lucia \& Hurtado Albir. "Translation Techniques Revisited: A Dynamic and Functionalist Approach." Meta 47.4 (2002): 498-512.

Mouakket, Ahmad. Linguistics and Translation: Semantic Problems in Arabic-English Translation. Aleppo: University of Aleppo, 1988.

Newmark, Peter. Approaches to Translation. Oxford: Pergamon Press, 1981.

Newmark, Peter. A Text Book of Translation. New York: Prentice Hall, 1988.

Nida, Eugene A. \& Taber, Charles. The Theory and Practice of Translation. Leiden: E.J. Brill, 1969.

Pym, Anthony. 'Venuti's Visibility' (Review of the Translator's Invisibility), Target 8.1 (1996): $165-77$.

Qasim, Maiysa. “At-tarjamatu fil-’assr il-'abāsī wa-dawraha fi tanaw'i il-'ūlūmi wa ma‘ārifi 'inda al-'arab." Afāq ath-thqafah wat-turath [Horizons of Culture and Heritage] 66 (2009).

Rieschild, Verna. "Words Between Languages and Cultures." Australian Style. June 2003. 27

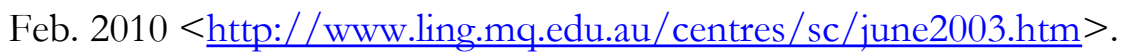

Salloum, Habeeb \& Peters, James. Arabic Contributions to the English Vocabulary: English Words of Arabic Origin. Librairie du Liban Publishers, 1996.

Sapir, Edward. Language, An Introduction to the Study of Speech. New York: Harcourt Brace \& World Inc, 1921.

Scandura, Gabriela L. "Sex, Lies and TV: Censorship and Subtitling." Meta 49.1 (2004): 125-134.

Schleiermacher, Friedrich. "On the Different Methods of Translating." The Translation Studies Reader. Ed. Lawrence Venuti. London: Routledge, 2004. 43-64.

Sharyan, Ayid. "A Pragmatic-Pedagogic Perspective: Constraints on Translatability of Arabic (Part III)." Yemen Times 12 Aug. 2009. 22 Feb. 2010 <http:/ www.yementimes.com/article.shtml? $\underline{\mathrm{i}=695 \& \mathrm{p}=\text { education\&a=1 }}>$.

Shunnaq, Abdullah. "Lexical Incongruence in Arabic-English Translation Due to Emotiveness in Arabic." Turjumān 2.2 (1993): 37-63. 
TranscUlturAl, vol. 1, (4) 2011, 103-122.

http://ejournals.library.ualberta.ca/index.php/TC

Sofer, Morry. The Translator's Handbook. Rockville \& Maryland: Schreiber Publishing, 2002.

Thawabteh, Mohammad. Translating Arabic Cultural Signs into English: A Discourse Perspective. PhD diss., University of Granada, 2006.

Thompson, John B. Ideology and Modern Culture: Critical and Social Theory in the era of Mass Communication. Cambridge: Polity Press, 1990.

Toury, Gideon. In Search of a Theory of Translation. Tel Aviv: The Porter Institute for Poetics and Semiotics, 1980.

Toury, Gideon. Descriptive Translation Studies and Beyond. Amsterdam \& Philadelphia: Benjamins, 1995.

Venuti, Lawrence. The Translator's Invisibility. London \& New York Routledge, 1995.

Venuti, Lawrence. "Introduction. Translation and Minority." Special Issue of The Translator 4.2 (1998): 135- 44.

Versteegh, Kees. The Arabic Language. New York: Columbia University Press, 1997. 